\title{
Women's Leadership Experiences: \\ A Study of Ivorian Women Primary School Principals
}

\author{
Rassidy Oyeniran (Corresponding author) \\ International and Comparative Education Research Institution \\ Faculty of Education, Beijing Normal University \\ 19 Xin Jie Kou Wai Street, Beijing 100875, China
}

Tel: 86-188-1303-1823_E-mail: rassidy2006@yahoo.fr; hariel.or1@gmail.com

\author{
Ishmael Bonjah Anchomese \\ International and Comparative Education Research Institution \\ Faculty of Education, Beijing Normal University \\ 19 Xin Jie Kou Wai Street, Beijing 100875, China
}

Tel: 86-188-1160-3079 E-mail: ishmaelbonjah@outlook.com

Received: April 20, 2018 Accepted: May 31, 2018 Published: June 9, 2018

doi:10.5296/jei.v4i1.13042ＵRL: https://doi.org/10.5296/jei.v4i1.13042

\begin{abstract}
Concerns about women educational leaders, their performance within primary schools, their approaches to leadership, including the hindrances experienced in the school headship have received few if any attention in Côte d'Ivoire. This paper analyses how women principals lead their schools and contribute to the schools' advancement in challenging situations that stand in their ways. The authors used a qualitative approach to collect data through in-depth semi-structural interviews with five female principals in Ivorian elementary schools. Findings showed that women influence directly teachers' commitment and indirectly students' learning process as well, particularly those who have learning difficulties. Data also revealed that these female used to create an environment and academic support that gives attention to children, as these learning conditions are similar to that of their actual life at home. Based on the findings, we assumed that women leadership could be a significant contribution to students' learning course, which in turn positively influence the school improvement. That is even consistent with the literature, which remains constant in the assertion that women
\end{abstract}


leaders own some abilities, such as being caring, attentive, patient. In this regard, educational practitioners, policy makers and stakeholders should pay more attention to women primary school principals for empowering them to display their know-how, expertise and talent useful for the students' learning process. That seems a possible backup for Ivorian education system to reduce the low academic achievement and enhance schools' performance.

Keywords: Woman principals, Leadership experience, Abilities, Challenges

\section{Introduction}

Historically, traditional African women played leadership roles in society and influenced society greatly. Yaa Asantwaa of Ghana, the queen mother of Ejisu in Ashanti and Zhinga Queen of Matamba in Angola are outstanding examples. Yet, women in leadership positions have to deal with a number of challenges that stand in their way, particularly when they are operating in the fields of men. Similarly, in Côte d'Ivoire the role of women has been of great importance in the history of the Akan people. Indeed, the history of the Baoule tribe is a remarkable testimony of the seventeenth century with the heroism of Queen Abla Pokou. Baoulé people owe their destiny to her, as she was the one who helped her people cross from the border of Ghana into Côte d'Ivoire over a shore of Comoé river to the other in order to escape the tribal war that arose at the time of the succession to the royal throne. Thanks to her foresight and especially her leadership, she thus saved her people from a planned elimination/subjugation while the destiny of the Baoulé people rested in their hands.

Besides, women have become the focus of international programmes and conferences. The UN's Millennium Development Goals (MDGs) adopted in 2000, following by the Sustainable Development Goals (SDGs) in 2015 have set up agendas to issue the key probems that concern the human being, including elimination of any kind of gender biases (UNESCO, 2016). Besides, Côte d'Ivoire has ratified a number of international and regional conventions, proclaiming the equality in dignity and in right (law) of all the human beings except the additional protocol for African Charter of Human Rights and peoples relative to women rights (Drame, 2015). Women who have become leaders or heads of institutions have successfully broken the barriers that traditionally stand in the way of women seeking career advancement. They have gone beyond the great divide. They have also broken the "glass ceiling" and have taken up leadership positions with the additional possibilities for power and influence they bring (Beck \& Steel, cited in Hall, 1996).

Women are now trying to reach high positions in organizations and institutions in Côte d'Ivoire. Examples are the current Grand Chancellor of the National Order, Henriette Dagri Diabaté, the nine women ministers in the Government and the Secretary of a political party, Kandia Camara. Apart from these women in leadership position there also women District Chief Executives, as well as women parliamentarians, school Inspectors, although the number is insignificant as compared to men, it is yet quite encouraging. This clearly indicates that women can occupy high positions in our country.

Despite all the concerted actions for the empowerment of women and the evolution of their rise to certain positions of decision-making and power, the gap still exists between men and 
women in many sectors. Empowering Ivorian women, it is not only a question of counting women in a few leadership positions to just fill the gap, but it is a matter of how they would be able to exercise their leadership roles. It is also, above all, how they would be able to influence important decisions through their ideas, intellectual and academic contributions in all instances without any discrimination. This means that their power should not be restricted at any level. The observation is that they generally suffer from prejudices that deter them from exercising power or downplay their decisions.

This raises the issue of females' representation in national instances taking into account the governance of the Ivorian institutions. Indeed, Ivorian women still experience various forms of difficulties. Many women in Côte d'Ivoire have no access to upper positions due to a discrimination and marginalization that prevent them from participating in professions and activities categorized as the preserve of men (Moreau, 2014).

Yet, participation is a very important ingredient in the social, economic and political levels of every society be it large or small, developed or underdeveloped, oligarchic or democratic. Those who are unable to participate, whether neglected or excluded, are likely to enjoy less power than those who participate. This is because those who are not able to partake do not feel part of what is going on in the society and therefore are not ready to take and accept any forms of decisions made by others.

Despites numerous initiatives to empowering women the promotion of women to upper positions or decision-making levels does not reflect the actual situation in Ivorian social and political context. In particular, the statistics of the educational settings give an example of the underrepresentation of female who still face challenges in leadership positions. In 2016, there were 12.125 men principals while women principals were only 923, and in May 2017, of 15547 primary school principals, the total number of women reached 1710 or $11 \%$ (MOE, 2017), which was still low compared to men's representation. Undoubtedly, this underrepresentation of women in leadership positions in primary schools raises concern of equity, equality and social justice in basic education as is the case in many other sectors. Yet, women seem to be good managers and effective leaders as referring to the existing literature (Eagly, 2007; Birnia, 2012; Muzvidziwa, 2014). However, leading people or a particular group is not easy and not linear, as there are many challenges particularly for women who are still struggling for obtaining better living and professional conditions and the recognition of their capabilities and abilities. Therefore, it is worth delving into women's experiences in principalship of Ivorian primary schools. 


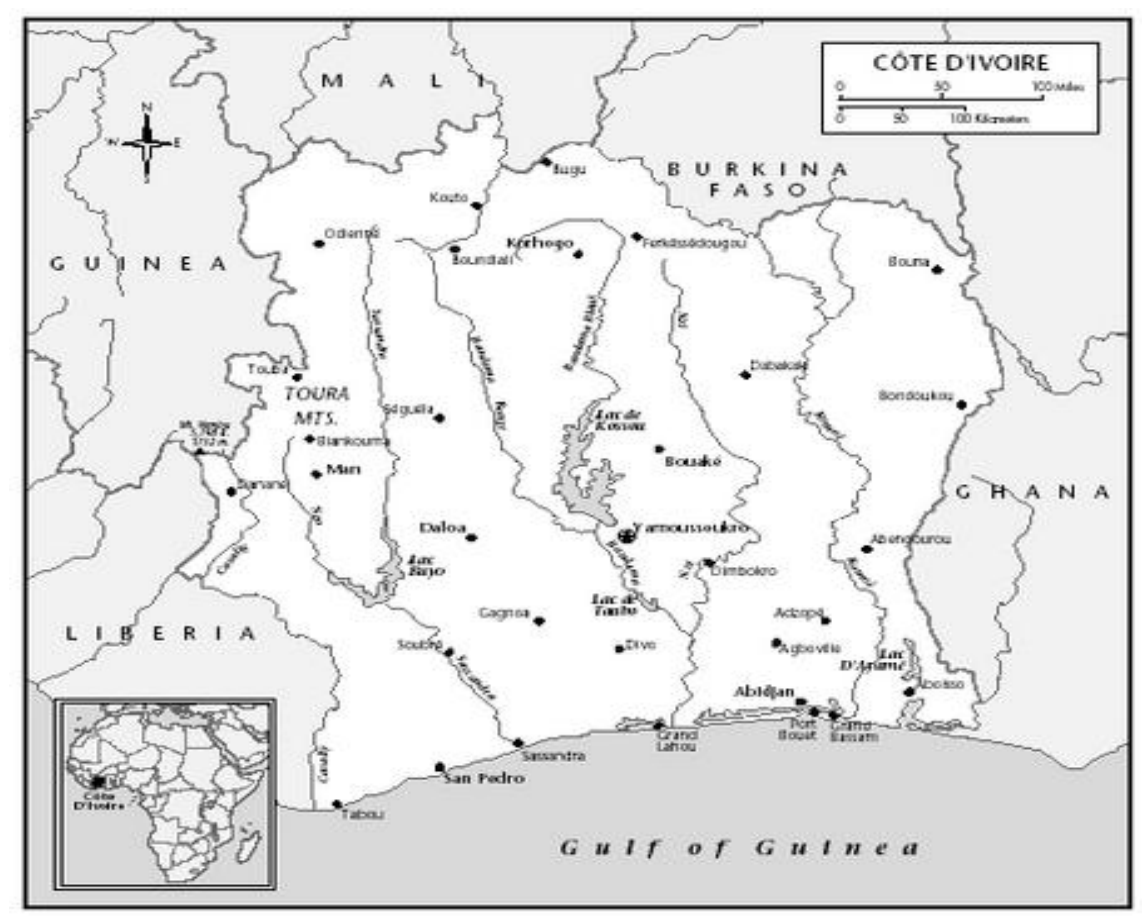

Figure 1. Geographical map of Côte d'Ivoire

Source: Library of Congress Online (2004).

\section{Literature Review}

The study explores leadership styles and practices employed by women principals through their lived experience as educational leaders, grasping a deep understanding of what principalship means for them while influencing the teaching and learning. The paper also examines their challenges within the school context.

\subsection{Women and Leadership}

Spillane, Halverson, and Diamond (2008) defined leadership as the identification, acquisition, allocation, coordination and use of social, material and cultural resources that establish the prerequisites for teaching and learning. It involves mobilizing staff, students to identify and tackle educational reform tasks and harness the resources needed to support the transformation of teaching and learning.

The work of the OECD shows that the notion of "leadership" presupposes the exercise of intentional influence by a person (or group) on other persons (or other groups), and is based on the formulation of goals to be achieved. The power of leadership is not the responsibility of one person, but rather can be shared among several people within and outside the school (Pont, Nusche, \& Moorman, 2008).

As can be seen from these definitions, leadership is first a process, that is to say there is a shared transaction between the leader and those who follow him/her; second leadership is also about influencing others. However, school leadership is not really a simple activity. It 
requires multiple and strong skills, regardless of gender. Since leadership involves influence, it implies cooperating with subordinates. The leader has to interact with people, and that is where conflicts or tensions may come from. In the context of primary schools, women principals continually deal with a number of challenges that might in one way or another affect women school heads.

School principalship seems to be a position quite known from outside; yet there are a number of experiences that may differ from the actual appearance. Indeed, when thinking about a school headship, the first image that comes to the mind is often that of the principal. The school principal is neither involved nor consulted regarding the recruitment of teachers, even less real and important influence on the pedagogy of the teacher in classroom. However, as the head of school he/she plans, organizes, directs, makes decisions and evaluates all activities within the school. Many actions and decisions depend on him or her and have a direct impact on school, students and teachers. Teachers and students are under principal's responsibility. The Head of school is primarily responsible for the operation and concerns of his or her school and students. According to Baume-Schneider (2008), investigation on the factors usually associated with school achievement specified unequivocally the role of management is a determining element of the mobilization capacity of teaching staff, associated with the high level of students' performance. This means that the quality of leadership and recognition of the "Principals" is now considered an essential criterion for healthy school (ibid: 10). Thus, because of that principal leadership style influence the work of all school members including teachers, the staff (all staff and management of the school) and student learning as well. However, school leadership is not really a simple activity. It requires multiple and strong skills, regardless of gender.

Constantly studies have shown that women leaders effectively lead their organizations; and the characteristics of female leadership are recognized as a positive factor for schools performance and transformation (Harris, 2003; Ogawa \& Bossert, 1995; Deal \& Peterson, 1999; Pitner, 1988; Kythreotis, Pashiardis, \& Kyriakides, 2010). Some studies also have shown that the women principals would perform better than their colleagues' men (Fortier, 2008; Martin, 2015). Yet women principals are under-represented and face obstacles in primary schools in Côte d'Ivoire.

\subsection{Underrepresentation of Women}

In many developing countries, the underrepresentation of females in decision-making positions is common, and well documented, raising issues of equity, social justice and sustainable development. Like in African countries, in Côte d'Ivoire, female remains underrepresented in various sectors, including academia. Men are outnumbering women in elementary schools.

Despite the political will, the gaps in gender parity remains and persist. Thus, in decision-making settings, according to statistics, women's current representation remains low: Parliament (10.5\%), Government (17\%), Economic and Social Council (17\%), Heads of diplomatic missions (13\%), Regional Advisors (11.33\%), City Counsellors (14.97\%), Senior Public Service and Public Institutions (26\%) (World Bank, 2017). Decisions have been made 
and implemented to attempt to increase women's participation in decision-making. $90 \%$ of women in rural areas grow food. It makes up $70 \%$ of the agricultural labour force (Moreau, 2014).

Despite concerted efforts of national and international organizations, women suffer from legal and factual inequalities in all fields, sectors. This situation is likely to create an imbalance in the evolution of Ivorian society. The socio-political crises $(1999,2002)$ and the post-election crisis (2011) have exacerbated the issue of gender equality, thus increasing the vulnerability of women. Like many countries on the continent, the 30\% women's representation rate recommended by the World Conference of Women, held in Beijing in 1995, and the parity advocated by the Solemn Declaration of the Heads of State of the Union African Women's Equality Forum in 2004, is not yet respected in Côte d'Ivoire (Tall, Kraidy, \& Noubissie, 2013).

In 2016, there were 12.125 men principals while women principals were 923, and in May 2017 , men were 13.837 while women were 1710 or $11 \%$ of total 15547 primary school principals (MoE, 2017). Even in 2016 in the economic capital city Abidjan, on 1467 principals working in the public schools in Côte d'Ivoire only $25 \%$ were women, leading primary schools in Abidjan (MoE, 2016). Thus, the question is: why men outnumber women in basic education, especially in primary schools?

Burke (2015) opined that the number does not matter itself, as numbers alone will not change gender inequality. She demonstrated that the fact that the high number of women in universities in UK is not sufficient to empower women or fill the gap between men and women. Burke's view is quite relevant, as a lot of cultural prejudice, stereotypes and moral and psychological oppression remain the greatest attitudes towards women, particularly from men. Thus, whatever the representation of the gender, what is important is how they are treated and perceived in higher education and what place is given to them. Therefore, the problem is not the number but rather the culture and practices that women experience within the system. Actually, it is difficult to understand that at the level of higher education a certain category is neglected and poorly recognized.

Nonetheless, whether the leadership is exercised by men or women, it involves certain qualities and abilities, which need to be demonstrated with regard to the school context generally full of challenges and obstacles that stand in the way of women principals (Oyeniran, 2018).

\subsection{Women's Challenges and Constraints in Leadership Positions}

As reported Ostergaard (1992) the total female labour force had doubled since 1950 with women constituting one quarter of women working force. These in turn are generating a larger demand for and supply of women's labour. In addition, decreasing fertility in some regions, reduced mortality and increasing rural-urban migration are both pushing and pulling more women into economic activities outside the household sphere.

Joekes (1987) emphasises that studies of women in society have shifted in the past forty years but not so in Côte d'Ivoire. Early writings revolved around women's traditional roles and 
centered on their position in the family in "primitive" societies. Men's and women's roles were considered essentially complementary. Narrow in focus as they were, such works were not intended to investigate the broader social and economic milieu nor even to consider economic aspect of different types of social organizations. During the 1970's the academic literature moved away from studying women in the family towards examining their activities outside the domestic setting and investigating their place in social and economic relations. Women's domestic role in rearing children and managing household resources is considered to be of central value to society. Women are systematically disadvantaged in economic and social terms hence this qualifies them for special consideration in all projects and programmes, not just in a separate category of women only projects.

In many societies in Africa, including Côte d'Ivoire, women have ascribed traditional roles. These roles are dictated by the societies in which they find themselves. According to Momsen and Kinnaird (1993), women's general work involves both monetised and monetised tasks both of which are crucial in household survival and rural development. Through the performance of such monetized tasks women contribute more to the household economy than their male counterparts.

Women's involvement in the country's socioeconomic development deserves close attention than hitherto acknowledged. Ostergaard (1992) maintains that women in development movement whether in its scientific, political or popular form has definitely drawn the world's attention to the fact that women represent powerful human in development that has over the years gone on unnoticed. They perform the major part of the world's labour and that they do so under very underprivileged conditions.

She further went on to say that women's activities are spread over various sectors of society, productive as well as reproductive. Women's role in biological reproduction and the bearing and nursing of babies is self-evident. It is a false stereotype, however, that because it is the "biological nature of women to bear children, it is a natural biological outcome" that for their lifetimes women should be obliged to do the entire housekeeping and domestic activities. Generally, gender bias encompasses both reproductive and productive activities. However, the workloads with regard to the domestic activities, maintain women's status quo, and reproduce the domination of men over women. This description results from the patriarchal conception and perception carried by people in the communities.

Education is moreover, a vital precondition for a fully productive life in the modern world. According to Joekes (1987), the picture of development since 1950 in this area, in fact, has some very positive features. Yet, in that case, women are firmly disadvantaged. There is considered disparity in educational provision for men and women. Though improvement has been made, much remains to be done to bring about equality, between the sexes.

Most women are educated, more employed and are employed at higher levels today than ever before, but they are still largely the glass ceiling realities (Reinhold, 2005; Jolls, 2002).

According to the AAUW's (2003) report, women have achieved greater changes in obtaining degrees, and they are more likely to work in decision-making positions and professional 
careers today. While women are increasingly likely to enter the paid labour force, they will probably continue to be presented with lower status service occupations, and that is just not good enough. Today the structure of global human resource has changed, a large number of educated women join the labour market and they play multiple roles.

On women's commitment to employment, it has been asserted that the real and perceived family burdens of married women are often cited by employers as reasons for their perception of female labour as more unstable and less committed than male labour (Ostergaard, 1992). Women workers are thought to take more time off for domestic duties and to leave the labour force at particular points of time such as at marriage or child birth. Employers are therefore less motivated to employ, train or promote women. However, there is little evidence to support these views. A study conducted by Evans (as cited in Ostergaard, 1992) demonstrated that the stability of Indian female labour has shown that women are less prone to leave their employment for better jobs. Studies on absenteeism in the organized sector show that the rates for males and females are fairly similar. A study has found that female absenteeism was usually related to family responsibilities and male absenteeism is based on alcoholism which is arguable for more serious problem for employers. Thus, the excuses of men for their absenteeism are very basic and not confusing to their employers. Women have so many responsibilities which are family and maternity problems which sometimes courses them to be absent at their workplaces. Men absenteeism can sometimes be based on leave and this cannot be compared to that of women in terms of absenteeism. Therefore, men have more advantages over women because of the men's opportunities described above.

There are still women who do not yet receive equal access to education. Besides, a number of schoolgirls drop out of school without completing their schooling. A UNESCO study revealed that women represented more than $70 \%$ of illiterates in Côte d'Ivoire (UNESCO, 2013), which does not favour large access to job opportunities. Moreover, the sexist stereotypes stemming from the patriarchal confine them in so-called feminine low-qualified and low-paid sectors. Social roles and gender stereotypes and discrimination are some major obstacles that most of researches on gender leadership focus on.

In most African countries, the weight of biological determinism is frequently cited to justify gender hierarchies (Rouamba \& Descarries, 2010), Côte d'Ivoire is not an exception. People, especially men are convinced that women are inherently less competent, which brings them to face hostility and doubts about their expertise because they are women (Oyeniran, 2018). Ivorian woman suffer from systemic bias in their evolution to the top-level positions, yet, as stressed Assié-Lumumba (1996), women played a significant role in the pre-colonial era in Côte d'Ivoire. From that time to the contemporary era, women experienced a number of hindrances while seeking for better social and political conditions.

Women face many obstacles in leadership positions, which are related to various forms of preconceptions in society who definitely believe that women are less competent than men in holding headship position. The sex-role stereotype has been shown to relate to the personal characteristics valued in leaders. Coleman reported that "The main gender-related problem for the women heads was the resentment felt by men and some women about females in a 
leadership role, the underlying belief that leadership is inappropriate for women" (Coleman, 2002 , p. 87). For women principals men were able to get things done but they hardly accept that women run. This is where frustration generally comes from (Wrushen $\&$ Sherman, 2008), as they talked about the hindrance they encounter on their ways.

As shown above, women globally encounter many challenges that stand in their trajectory when moving towards effective leadership. In Côte d'Ivoire, Ivorian women experience almost the similar situation, especially when it comes to occupying leadership position or to empowering female in decision-making levels. Most of the strategic positions are male-dominated. However, women themselves are sometimes responsible for the undermined situation. At times, it difficult to explain why they are reluctant to take up headship roles or responsibilities. Women often lack of confidence in themselves, fear of failure. Some authors justified this reluctance by the fact that women are victim of stereotyping perceptions, or they have limited ambitions (Andela, Escandon, Garlo, \& Kamungi, 2008).

\subsection{Purpose of the Study}

Despite a growing emphasis placed on the importance of gender inequities with regards to the school context, very little studies, if any, explore women's leadership experiences in the the primary school settings. Therefore, this qualitative case study sought to uncover the lived leadership experiences of women heading primary schools in to understand the major challenges they face, and to shed light on strategies used by women school heads and hindrances experienced in school principalship. It seeks to delve into the women's experiences to grasp the actual realities in their principalship roles. Indeed, as leaders women heads school face some realities with regard to the issues related to their status, but they may experience life and work differently depending on the school context.

\subsection{Research Questions}

What are the characteristics of leadership women principals use?

Dhat are the key challenges women school principals face?

> How do women principals overcome hindrances they encounter in principalship?

\section{Method}

The researcher used qualitative design along with phenomenological approach to conduct this study (Yin, 2014; Denzin \& Lincoln, 2005). Qualitative research informs an interpretative accounts of participants and is comprised of several characteristics that strengthen its use in researches. The researchers used a purposive sampling to select a limited number of sample (5 schools). Patton (2002) suggested that purposeful sampling is the most suitable approach in qualitative research as it provides rich information from the cases that are studied in depth. As stressed Miles and Huberman (2003), it is possible to approach a phenomenon and build up a model from an inductive approach. In this regard, this exploratory research study for investigates the principalship experiences of the participants. By exploring women principals' experiences in principalship position, the study sought to gain a deep understanding of women opinions, motivations and insights. 


\section{Macrothink}

As per the criteria set up, women principals' ages were ranged from 40 to 50 years, in addition the researcher look at the criterion of 10 years professional experience in teaching profession or in the domain of education. Table 1 shows the sample for the study. The female leaders selected were from eleven (5) elementary schools located in Abidjan District, Côte d'Ivoire's capital city.

A qualitative approach, which suggests the use of phenomenological-interpretive case study technique, is used for collecting data through semi-structured interviews with the five women principals. The phenomenological perspective offers ways of a deep understanding of individual's experience (Campell, 2004) rather than examining surface features. To grasp the women's insights and meaning they give to their life, the researchers give them opportunity to tell their stories, including their work experiences, perceptions, vision, and expectations in narrative way. The women in this research expressed themselves in terms of how they perform their roles as school heads and accomplished their goals.

Data were collected from semi-structured interviews with the participants to learn about the current issue. A voice recorder was used to compile the information. The interviews took place in the schools within two weeks and lasted 45 minutes for each informant.

Participants were identified under codes to ensure the anonymity. The participants were renamed as Anissa, Kathy, Larissa, Antonia, Brica. The data were transcribed and coded systematically according to specific themes and then analysed to address the research questions (Creswell, 2014).

The analysis led to common patterns and themes. The coding process involved grouping the statements of the participants based on the relationships, before categorizing them to reach the identification of main themes emerging from the raw data. Constant comparative analysis of data allowed to establish emerging themes. Findings from the interviews were analysed thoroughly and narratives considered by the use of quotations from respondents. Data audio-recorded was transcribed by categorizing the meanings.

\section{Findings and Discussions}

\subsection{Description of the Participants}

The selected women for the present study were presented shortly in the table below with their demographic information. Among the five informants, focus was placed on two females to further the discussion. 
Table 1. Participants' background Information

\begin{tabular}{|l|l|l|l|l|l|l|l|}
\hline Pseudonym & Age & $\begin{array}{l}\text { Highest } \\
\text { degree } \\
\text { Earned }\end{array}$ & $\begin{array}{l}\text { Years of } \\
\text { Teaching } \\
\text { Experience }\end{array}$ & $\begin{array}{l}\text { Years of } \\
\text { Principalship } \\
\text { Experience }\end{array}$ & $\begin{array}{l}\text { Years in working } \\
\text { as Principal in } \\
\text { Current School }\end{array}$ & $\begin{array}{l}\text { Marital } \\
\text { status }\end{array}$ & $\begin{array}{l}\text { Number of } \\
\text { Children }\end{array}$ \\
\hline Anissa & 55 & BEPC $^{2}$ & 30 & 13 & 10 & Married & 3 \\
\hline Kathy & 56 & BAC & 32 & 17 & 12 & Married & 4 \\
\hline Larissa & 45 & BAC & 23 & 8 & 5 & Single & 2 \\
\hline Antonia & 43 & BAC & 20 & 5 & 3 & Divorced & 1 \\
\hline Brica & 41 & BAC & 16 & 5 & 2 & Single & 1 \\
\hline
\end{tabular}

Note. ${ }^{1}$ Pseudonyms were used in the study.

${ }^{2}$ The degree of the fourth grade of high school.

${ }^{3}$ A test taken by students in France and some other countries (French Speaking Countries like Côte d'Ivoire) in order to qualify for attending a university.

In Côte d'Ivoire it is the degree of bachelor conferred by colleges and high school, the degree obtained to join University or Vocational high school.

As mentioned above two women participants (Anissa and Kathy) had opportunity to express deeper into their perceptions and experiences in leadership positions. The following subsection provides more details of these two female principals.

\subsubsection{Anissa}

Anissa grew up in a large family environment. Her father was polygamous. Anissa was married with three young sons. She lives near her current school. Anissa described her parents as very rigorous and had working persons who emphasized on the respect and the ethic. Her parents always kept reminding all their children to target the excellence.

Being the elder, Anissa's parents taught her how to manage her little brothers and sisters. Today she know how to manage people. Anissa was a reserved girl, but life taught her how to be sociable.

Anissa holds a BEPC and has been teaching for 30 years. Anissa's career path began as teacher assistant, and her administrative career began as deputy principal, and, then, she was promoted as principal since 2004 and she already served for 10 years in the current school that was closer to home. The trajectory to educational position was not easily travelled. The road to headship was quite competitive as she failed twice before getting her current position.

Anissa always loves to teach first grade because she like to stay with little kids. Anissa says, "I love to see them growing up and improving their reading skills". She considers herself as 
someone whose role is to coach pupils. "I see myself more as a trainer than principal. Principalship is full of principles whereas coaching brings me much more close to my students". However, Anissa feels that heading a school is quite challenging than she thought.

\subsubsection{Kathy}

Kathy stated that her parents educated all their kids rigorously. When she was 14 years old, her stepmother came to relieve her parents. She acknowledged that woman influenced very much her life, as she was so tough with her. Although, Kathy was a very reserved woman, she was always good-humoured. Her father was a driver and her mother was a housewife. School fees were so expensive that her parents could not afford to pay them, as they have been living in a fairly modest conditions.

When Kathy wanted to apply for the principalship she has been discourage several time by her boss. She has been appointed principal for the first time in 2005. Kathy acknowledges that her family has played an important role in her life.

From the interview of these two female, the research noted that they experience the principalship differently. Since she lives alone with her children, Anissa began very to organise her life and count only on herself when she faced challenges or obstacles.

"I raised alone all my three children without any support, that was one of the big challenge for me in my life, as my husband leave us (my kids and I) earlier. I did immense sacrifices for my kids, experienced privations and struggled any and over times because of their future and their success" ... With my meagre salary it was not evident. (Interview, WA201704)

Unlike Anissa, Kathy still lives with her espouse and their four children. However, she revealed her own experiences. She described her life as a testimony. She expressed,

Despite her administrative position, Kathy is still a victim of sexism,

When I was child, I had a dream. My dream was not the same as that of other children. I desired to become a remarkable girl of my generation ... the best student in my school. I was lucky to have a family that supported me and encouraged me to pursue my dream. I learned how to be dominate fear ... I also learned how important it is to fight for your own dreams, and more importantly to aim the top. My struggle started when I was three years old. (Interview, WK201704)

Kathy feels that women are not encouraged enough to pursue their dreams. She acknowledged that people even discouraged them. It happened; people fight against her opinion or vision just because of her gender. She felt "can you believed that in our era of $21 \mathrm{~s}$, and especially in an academic setting", and commented,

Women have to break down many barriers on their way to success. One of them is the fact that we are constantly reminded that we are not men, as if it were a fault. Women must always be judged by our successes, by what we have achieved, not by our sex (Interview, WA201704). 
The above description of women provides insights about how most of women principals experienced their principalship, and how their considered their job. This is important as the leadership experiences may vary according to the daily tasks and school context.

\subsection{Women's Leadership Experiences}

\subsubsection{Why Women Lead Differently?}

The question here was to identify and understand what features of female leadership can help students in their learning. In this study, the women leaders performed differently within schools District. There is no doubt about their ability to run their schools. However, the styles of their leadership were influenced by the actual situation depending on the nature of the problems they faced and the goal they targeted. Antonia sees herself to be more democratic than autocratic while Kathy said,

I used to be myself when I am working ... I keep in my mind I am working with people like me ... so I just remain natural as possible and I try to focus on the tasks. When I was vice principal I work under a man principals for five years. I used to talk with some of my colleagues male when we meet. From our meetings and discussions, I experienced how men usually perform in leadership positions. I don't think men and women use the same style in the primary schools. Also, I think women have somethings different which is part of their nature. (Interview, WK201704).

This perception is in the same line with what some authors (Rigg \& Sparrow, 1994; Brinia, 2012) have demonstrated. In fact, theses scholars showed that characteristics leadership of women primary school principals are described as emotional, sensitive, and expressive. Other studies have demonstrated the emotional practices of women school heads as they mostly operate within a dynamic context. Certainly, that is why Sachs and Blackmore (1998: p. 272) stated that "the complexity of life in schools and the daily exigencies of their professional and personal lives gave rise to a variety of emotions", as women nourish emotions of care, especially when they are involved with schoolchildren matters. In this study, women principals seemed to attach great importance to the learning and social-well-being of their pupils, which as result creates a caring school climate.

Furthermore, Hooks (1994) reported that during her twenty years of teaching many students still seek to enter feminist classroom because they continue to believe that there, more than in any other place in the academic, they will have an opportunity to experience education as the practice of freedom. That is means when it comes to instructional matters, women are naturally more open, and they inspire confidence in their teachers and learners. Thus, these abilities are of great important in students' involvement and make them performing.

Nowack (2015) has found in women inclination to leadership a particular characteristic. The author reported uncovered a natural predisposition in women's biologic structure. This study is not debating the psychological perspective of women behaviour nor the biological tendency, rather in this point it's trying to undersatand why women that it under pressure are more emotionally expressive or empathetic when involving with social interactions as argued Nowack (2015). 
This natural and biological predisposition that Nowack pointed out could significantly be compatible with the supervision of children in schools. With the guiding, their listening and attention skills, women will be able to understand and respond effectively to the expectations of learners, especially those who need special attention due to their low level or social emotional learning issues. In this case, school principals are the ones who can talk with students and parents and take appropriate decisions for each student with special needs.

School is a social institution that needs a calm social climate, and the fact that women adopt a natural approach and others based on participation makes pleasant interactions between teachers and between students themselves. The leadership of primary school principals has the distinction of being oriented leadership student needs and contributes to the social-emotional development of those and that encourages and mobilizes tactfully teachers and staff in view of the educational project.

\subsubsection{What Makes the Difference?}

The question is, what characteristics of leadership styles these females used and how they manage their schools. The selected women considered themselves as open mind leaders, caring about human being. Most of the teachers described these women as heads who motivate their agents, especially the teachers whose teaching in turn influence positively the students' academic performance. Regarding female principals' practices within and out of the schools it is recurrent to see women more are more sociable, while men are less socially sensitive and men are more focused on pragmatic aspect. Women encourage personal development.

(1) Inter-relation Based Management: Relationship and Communication Skills

Most of the women considered that it necessary to establish a good relationship with the staff, team members and students within and outside the school. The researchers witnessed this approach in their behaviours for time the spent with these female during the present study. Anissa confirmed,

My duty is to treat my employees so that they can perform properly. I give personal attention to people, especially students who seem having personal or academic problems, like deficit of attention, less confidence, reading and spelling matters ... To me, a leader must be closed to the students in term of being their tutor and monitor. As the head of school, we are the ones who should encourage and support students in their learning, in the sense that we responsible for school outcome. (Field-notes, WA201704)

As for Kathy, she oftentimes used to reward students and sometimes complimented teachers as necessarily as the work is going on. Women principals believe that pupils deserve the most significant consideration when making decisions.

From the findings, it came out that both schools there is a kind of positive relationship between the leadership exercised by women principals and student outcomes, as referred to the participants' accounts. When asked women schools heads how they perceive the correlation between leadership and student achievement, they referred to their managerial 
skills as well as their commitment to the instruction.

Kathy mentioned, "I used oftentimes communication and advice. I keep a positive frame of mind. I think people approach me easily. I make the effort to do not to others, that is to say my staff for a team".

Antonia commented,

By supporting these students feel valued and confident at school as they adhered to my educational vision. Teachers also cooperate with me on most of the subjects and the sensitive affairs as well. This is my approach of treating students by encouraging speeches, empowering and motivating them to work. I even know my students individually, their names and I try to know their major needs as I am very close to them and I am interested in the details of their learning. Consequently, they feel safe. (Interview, Wa201704)

The above statements are in accordance with what Conner (1992) described as women distinctive orientation. Indeed, for Conner women leaders prioritize attention to others, focusing much more on relationship, which includes school board and community

Brica participant observed,

The leader must create a school environment that makes students comfortable and confident. Despite I am a teacher I spend a lot of time to visit the classes to ensure that students and teachers are working. I make the decisions after obtaining the opinion of my staff members and teachers. Furthermore, I organize building courses for students and ask parents to keep children at home. (Interview, WB201705)

Teachers agreed that women's management style promotes communication. Women are more interested in sharing and circulating information. A teacher shared a bit from his experiences since he has been working in different elementary schools under male and female heads,

For women, all information is valuable and they prefer to focus on documents that represent potential sources of information for the school. As for men, they can draw their information from their relationships and their networks regarded as some of their strengths. Women communicate very much; they like to listen and tend to give more details about information when they meet parents. (Interview, WT201705)

This is in line with what Bergeron (2006) and Lapointe, Brassard, Garon, Girard, and Ramdé (2011) who found female principals feel completely comfortable in the role of promoting the information about their schools, as they tend to be much more communicative than their colleagues men are. Thus, female managers would be more at ease in the role of broadcaster.

(2) Instruction Prevalence: Supervision and Time Regulator Skills

From the verbatim accounts, the researchers note that women tend to devote more time than their colleagues men to educational activities do. Antonia asserted, "I personally give special attention and time to see and review how children are doing and how they learn ... I also used to supervise the school activities and learning to make certain that everything is done 
correctly, safely and on time".

Based on the verbatim accounts, the inquirers note that women leaders in this study used to spend more time with their staff members, involving them in the pedagogical matters. Actually, most activities that the women principals focused on are related to the teachers' evaluation and supervision process.

The principals devoted much attention and care to issues around the instruction, organizing activities that work for the professional development of the school staff members. It seemed the objective of monitoring their personnel is to be empowered, which would be the source of school improvement. Actually, the school improvement is one of the current subject that the Ivorian Ministry of education focuses on to catch up the delay that Côte d'Ivoire has experienced during the last ten years of socio-political crisis that has weakened the educational system. In fact, school improvement is more about processes; it is a special approach to educational change that aims to improve student outcomes as well as the school's ability to accomplish change and improvement. One of the participant, Antonia, asserted, "I personally give special attention and time to see and review how children are doing and how they learn ... I also used to supervise the school activities and learning to make certain that everything is done correctly, safely and on time".

In particular, school improvement is concerned with improving the student's performance by focusing on the teaching-learning process and the conditions that support it (Hopkins, 2001, cited by Berger, Norberto, Soussi, Giorgio, Gauvreau, \& Heinz, 2004). In this perspective, women principals play the valuable roles of coordinator, coach facilitator as suggested Fortier (2008). In this regard, women school heads would favour quality life at workplace and the performance of their subordinates, as they give enough importance to teamwork roles by using efficiently the working time.

In this study, it is clear that women principals committed themselves to the common goals that would be sources of motivation for most of their school members (Héon, Savard, \& Hamel, 2008). For Gauthier (2007), the educational initiative must be at the heart of the institution and can only come from a collective commitment. Looking at these women leaders tendency to lead, school leadership it is not all about personal authority or power of the leader who would impose a kind of pedagogical power, but the function of pedagogical initiative that each teacher must be an owner of that power, which must be distributed among them, and coordinated by the school head. Other scholars like Gross and Trask (1976), and Shakeshaft (1986) suggest that women principals are more concerned with the socio-affective development of students and are more sensitive to the peculiarities of the students.

(3) Women as Problem Solvers

How female leaders handle problems within schools was also concerned the research, as it seems women are good at solving problems (Zaid-Alkilani, 2015); they are well equipped for the workplace issues and are more able to cope with unexpected conflicts. Women in this study have shown their readiness to dealing with ways of working at schools. It seemed this advantage stem from their childhood as they have been brought up in families' environment 
from where they took their ability to handle people as well as their behaviours. As part of their management, they tend to take advice from the extended family. Besides, what strengthen their competence to effectively solve problems is that they pay more attention to details and everything that happens around them and especially to the relationship. This allows them to identify earlier the possible tensions between individuals, thereby anticipating solutions or avoiding conflicts by means rather diplomatic.

From the observation in this study, the researchers noted that women principals perform well in problem solving. An illustrative example of that is Brica, who knows quite well how to go about issues as she used to be proactive in approaching any kind of problems. She elaborated,

... when a misunderstanding arises between teachers or between students, I first use adequate and smooth words to create a kind of friendship debate in a very calm manner (...) Because I always want to keep fraternity in my school, that I am sure touches positively the individuals in conflict. That is one of the important thing I think any leader should ensure for the sake of the school members. I have been solving more tensions than I expected ... But it is not surprising to experience such kind of conflicting situations as the school is a dynamic space. A couple years back, I have been involving in the arrangements to end up tensions and conflicts between teachers and parents ... (Interview, WB201705)

The above account demonstrates how much Brica is sharp. Most of the time she's used to dealing with difficult situations and individuals and she successfully did it. The way she behave confirmed what Morsink (1970) also found. In his study, Morsink observed that female principals are more effective in resolving conflicts with teachers. In fact, in women approach of leadership dialogue and communication are emphasized, as such they are excellent in conflict management and resolution because they demonstrate strong evidence of qualities such as patience, empathy, discretion and diplomacy. Women use co-operative attitudes, teamwork skills and possess a strong sense of responsibility.

\subsubsection{Transformative Leadership Tendency}

\section{(1) Caring Focus}

By observing women principals performing and listening to their narrated experiences, it is safe to say that women principals are worried about the pupils' social well-being, as well as people within the school. Kathy viewed herself as a caregiver individual for teachers, especially for some of the children who have specific learning difficulties. This would mean that there are students who face many problems that female heads school need to resolve with their know-how, i.e. natural abilities. That was a point that Gross and Trask (1976) found in a study, which revealed that women principals were more concerned for deviant pupils.

The majority of women in this study emphasized participative, collaboration, caring as characteristics of their leadership. Besides, they described their self-perception of style as transformational leadership. Several studies (Eagly \& Johanassen-Schmidt, 2003; Lortie-Lussier \& Rinfret, 2007; Eagly, 2007; Bass, Avolio, \& Atwater, 1996; Bass \& Riggio, 2006; Holmes, 2005) pointed out that, women leaders are known as having transformational 
skills and adopting individualized consideration towards people than men. Research into leadership styles found that transformational leadership emphasises empowerment of followers including a shared vision. Besides, transformational leadership emphasises individualised consideration (Bass, 1985; Eagly, 2003) and providing a role model for ethic of care (Gilligan, 1982), which encourages respect and trust (Mascia, 2015).

Individual consideration has great importance in managing school, in sense that there are students from diverse and different background and origins within school. Justice, equity and solidarity should be promoted based on the ethics and inclusion. Gilligan (1982) approached moral development of women in her research and found an ethic of care and sensitivity displayed by female in their leading role.

From her experiences, Anissa perceives herself as a head who tend to manage people with maternal instinct in the sense that she is quite sensitive to the well-being of others, to the socio-affective evolution of others, and to be very attentive to their needs. She used to display a motherly care approach when dealing with pupil behavioural problems or when approaching the cases of children who have learning troubles. She declared:

I came to realise that motivation, perseverance, and self-esteem are the key elements of students' academic success. These factors strengthen the child's desire to love the school; as the head of my school, I try to help them with the sole goal of succeeding by paying particular attention especially to those who have learning difficulties. From my experiences, I must say that involvement in students' concerns, love and individualized consideration are of great importance and play significant role in students' performance. (Field-note, IM201705)

\section{(2) Collaboration Focus}

The women who participated in this study demonstrated and develop more collaborative approach of leadership, increasingly stimulating and inspiring. They put the emphasis on teamwork, dialogue, listening, empathy and consensus. They also used inclusive approach. Antonia described her style in terms of caring people in her school:

I lead my school by adopting relational and collaborative management approach; I encourage and mobilize for the participation of all in the task. I also emphasize on team spirit, sharing power and information, even though some tasks take up most of their time. To me, collegiality is at the heart of management, a method closely linked to the participatory style of management; that empower followers and likely generate good results. (Interview, IM201705)

Collaborative leadership is abundantly discussed in the academic literature, which suggests that collaboration in modern organisations creates effective teamwork. Judge and Piccolo (2004)'s studies have demonstrated the positive relationships between leadership styles and measures of the effectiveness of leaders. These scholars found that transformational leadership was one of the greater source the school effectiveness. Eagly and Johanassen-Schmidt (2003) also came to the conclusion that women leaders were more 'transformational' than colleagues men. 
Other researchers have found that women are better than men are at transformational leadership, especially in leading teams. For example Carwright and Gale (1995) conclude that women were people-oriented, and they seemed having better communication skills than males (Lee \& Sweeney, 2001). Though women principals in this study possess abilities and assets as discussed, they experience a number of hindrances that affected their principalship and themselves.

\subsection{Women Experiencing Challenges and Constraints in Principalship}

\subsubsection{Socio-cultural Factors Affecting Women in Principalship}

The findings revealed that challenges faced by women school leaders includes socio- cultural entrenchments that they have to deal with, especially in the schools. Almost all the participants, including Anissa and Kathy emphasized that culture reflected in the set of perceptions, mindset and practices in the schools and the local communities disturb negatively women leaders when they are running the schools. Anissa stated: "Community, including parents hardly admit or accept women heading the school where their kids are schooled; they always associate the headship with men".

Women school principals also experienced resistance from their teachers, especially older male teachers. That happened most of the time when these female made decisions or took initiatives for changes. That cultural mindset and perception on women leaders of schools affected their headship. Kathy observed, "I faced challenges such as disobedience, defiance from men teachers as they do not want to be controlled or supervised by me because I am a women". That concur with what Anissa said, "one day, upon my arrival at this school, some of the teachers declared that I will fail in my administrative role ... they cannot follow nor accept to apply any decision from me". These cases of confrontation and insubordination come from the fact males feel being undermined by the female authority. For men, women are weak in making decision effectively and they lack good leadership skills. Sociocultural perceptions are heavily embodied in male mind as teachers displayed disrespectful behaviours towards women heads. This nature of paternalistic cultural hurdles is found in Mollel and Tshabanbu's (2014) study.

\subsubsection{Organizational Factors Affecting Women in Their Principalship}

Decision making power of female is oftentimes inhibited by the hierarchy, such as the Inspector or the Executive Director, as the Ministry of Education is highly hierarchized and branching out. Again, there are ideas that prevail women have lesser career trajectory than men due to the fact they get pregnant and take care of children when they are sick. Thus female are not always available for the responsibilities. Moreover, Ivorian women principals' voices are unheard when it's come to defend themselves or to reveal their actual experiences as it came out that structural factors impacted negatively on them. That is why women are still under-represented in the leadership and decision-making positions (Cubillo \& Brown, 2003). The path to the top position for female remains full of challenges and hurdles. The consequences of the obstacles are that men still outnumber women in holding in principalship. 
The women leaders confirmed that they also face other structural constraints, as they seek to balance home life with office demands (Brown, 2004). Women are committed to handle the triple roles (teaching a class, leading the school and managing the house) while their colleagues male tend to have more relax times, do less effort and get less stress, than those of women.

\subsubsection{Overcoming the Hindrances}

In this study, women principals were asked how they deal with the problems and overcome the obstacles.

As the eldest of my brothers and sisters, I learned how to handle difficult personalities as my parents have played a great and significant role in how to approach and to deal with complex situations very well when emotions, crises, or conflicts came up between my little brothers and sisters.

That sharped very much her ability of leading people. She also used patience to manage her teachers and other school community member. Kathy regards herself as both a maternal and caregiver person, especially with the children. I always offer the motherly role with the pupils. Teachers acknowledged that Kathy's strength allowed to be always very hard hardworking at school.

She used to visit the classes and involved in classroom management to make sure all is well. She even knows the names of each student and she is very much concerned about the welfare of students within the school. Like Kathy, Anissa also loves to stay with pupils. Anissa perceives herself as a teacher than prinicipal, as for her leading a school has nothing to do with teaching. Teaching bring closer and is not a separate from helping students in their learning.

I used to have discussions with my students to help them, especially with those who need support to overcome their difficulties. That's why I decided to teach the pupils of CPI (the first class of primary) because they need more supervision, monitoring and support ... At times the kids need just to get confidence and it is our role and our duty as head of the school to give them comfortable and peaceful environment, and create good climate within the school.

Anissa used to associate the teachers, school and parents staff asking for their opinion on certain issues related to the school before taking important decision. She believes that leading a school is more about how to mobilize teachers, school staff, parents and school community for the wellbeing of students. She further elaborated, "I love my students and I take good care of them (...) I am always in the view that leading the school also enable students themselves to grow up by empowering them. Muzvidziwa (2014) explained that women principals display a motherly care approach when dealing with pupil behavioural problems. From that observation it's can be admitted that school should be a wealthy space where students can express successfully himself with motivation empower by the head school. 


\section{Conclusions}

\subsection{Key Results Revisited}

This study shed light on women' lived leadership experiences in primary school settings. The findings revealed that women principals were collaborative, team-oriented and caring among others qualities. The study has mapped out how in their principalship, women's interactional tendency to lead is undoubtedly at the basis of their educational abilities and creativities. Besides, women participants in this study do not exercise their power just for power; rather leadership means for them a ways to empowering and caring people they work with or look after, especially the students. Actually, these women considered the educational settings as the spaces where the learning and teaching process should be involved in less hierarchical rapports, and more humane. Sharing and learning together seemed to be ways of strengthening their leadership, and they used that as the source of their positive influence over their school members including the staff and the learners. As revealed the findings, these women principals operated in an inspiring school context, caring for others and practicing collaboration as a way keeping their school under a peaceful space. However, it came out of these educational leaders' experiences a number of challenges and constraints that mainly affected their headship. From the findings, it was clear that being school head is not only influencing, controlling and supporting the school nor having just certain assets; it also being aware of difficulties and getting always ready to surpass a number of obstacles that may arise. This category of women leaders were tangible examples of courage and perseverance. The researchers assumed that despite the apparent quietude and peaceful environment within the schools, women principals had to deal with challenges. Among the challenges that hinder women's principalship, there was a set of socio-cultural and organizational obstacles along with stereotyping perceptions and attitudes that undesirably affected their principalship roles in one way or the other.

\subsection{Limitations of the study}

The current study has some limitations. It investigated the leadership experiences of Ivorian women principals. It was limited to the accounts from the selected women principals. Besides, it was limited to Abidjan district and is thus not generalizable to other regions. As the findings of this qualitative case study are specific to a small number of a particular environment and participants, it is impossible to demonstrate that the findings and conclusions are applicable to other situations and populations (Shenton, 2004). The results may not match another group of women school principals or may not be transferable to a study that would be piloted elsewhere because women's leadership experiences may be different depending on the context and the culture.

\subsection{Recommendations}

Participation without the power to influence decision is an empty ritual of frustration of the powerless. Women, therefore, require higher education, financial empowerment and support, strict implementation of the quota system, personal development. The study advocates initiating a concrete incentive for women's participation in the political, social and 
economically decisions. Besides, the researchers feel women should be part of policymakers thereby promoting women in school headship to minimize the gender gap. That would be a way of empowering women in basic education. In particular, there is a need of "protecting" women against stereotypes, socio-cultural biases and paying close attention to women's principalship by giving them opportunities to express their full potential and meet the school goals.

\section{References}

AAUW (American Association of University Women). (2003). Women at Work. In S. K. Dyer (Ed.), Educational Foundation report. American Association of University Women Educational Foundation. Retrieved from https:/files.eric.ed.gov/fulltext/ED534503.pdf

Andela, C., Escandon, S. D., Garlo, C. K., \& Kamungi, P. M. (2008). Women of Africa Leadership Development Program Combined Research Report: Kenya, Liberia \& Côte d'Ivoire Research Period September 2007. Retrieved on October 6, 2016, from https://www. sfcg.org/programmes/lwi/documents/WomenOfAfrica_Liberia_IvoryCoast-FRENCH.pdf

Assie-Lumumba, N. T. (1996). Les Africaines dans la politique: Femmes Baoulé de Côte d'Ivoire. Paris, L'Harmattan.

Bass, B. M. (1985). Leadership and performance beyond expectation. New York: Free Press.

Bass, B. M., Avolio, B. J., \& Atwater, L. E. (1996). The transformational and transactional leadership of men and women. Applied Psychology: An International Review, 45(1), 5-34. https://doi.org/10.1111/j.1464-0597.1996.tb00847.x

Baudoux, C. (1987). Caractéristiques de gestion des directrices d'écoles secondaires. Revue des Sciences de l'Éducation, 13(3), 355-406. https://doi.org/10.7202/900572ar

Baume-Schneider, E. (2008). Être directeur d'un établissement scolaire aujourd'hui: Un vrai statut pour un rôle essentiel. Bulletin de la Haute École Pédagogique de Berne, du Jura et de Neuchâtel. Haute École Pédagogique (HEP-Bejune).

Berger, E., Norberto, B, Soussi, A., Giorgio, O., Gauvreau, C., \& Heinz, R. (2004). De l'émergence du courant «School improvement» et exemples d'applications. Revue Française de Pédagogie, 148(1), 119-134. https://doi.org/10.3406/rfp.2004.3255

Bergeron, P. G. (2006). La gestion dynamique: Concepts, méthodes et applications (4th ed.). Montréal: Gaëtan Morin Éditeur.

Brinia, V. (2012). Men vs. Women; educational leadership in primary schools Greece: An empirical study. International Journal of Educational Management, 26(2), 175-191. https://doi.org/10.1108/09513541211201988

Brinia, V. (2012). Men vs. Women; educational leadership in primary schools Greece: An empirical study. International Journal of Educational Management, 26(2), 175-191. https://doi.org/10.1108/09513541211201988

Brown, H. E. L. (2004). Barriers to women in educational leadership roles in Montana 
(Doctoral Dissertation, Bozeman, Montana: Montana State University-Bozeman).

Burke, P. J. (2015). Reducing gender equity to a battle of the sexes is simplistic, crude and dangerous. The Guardian. Retrieved from http:/www.theguardian.com/commentisfree/2015/ mar/08/gender-equity-battle-of-the-sexes-simplistic-crude-dangerous-universities

Campell, B. (2004). Phenomenology as research method. Victoria University of Technology. Retrieved from http://www.mieonline.org/home/categorie/Articles/Researcxh-Methodology

Coleman, M. (2002). Women as headteachers: Striking the balance. Stoke on Trent: Trentham Books.

Conner, N. L. (1992). Restructuring schools: Will there be a place for women? Clearing House, 65(6), 337-339. https://doi.org/10.1080/00098655.1992.10114240

Creswell, J. W. (2014). Research design: Qualitative, quantitative, and mixed methods approaches. Thousand Oaks, CA: Sage.

Cubillo, L., \& Brown, M. (2003) Women into Educational Leadership and Management: International Differences? Journal of Educational Administration, 41, 278-291. https://doi.org/10.1108/09578230310474421

Deal, T. E., \& Peterson, K. D. (1999). Shaping School Culture: The Heart of Leadership. Jossey-Bass, San Francisco, CA.

Denzi, N. K., \& Lincoln, Y. S. (2005). The SAGE Handbook of Qualitative Research (3rd ed.). Thousand Oaks: SAGE.

Drame, A. (2015). La situation des femmes en Côte d'ivoire vingt ans après Beijing Communication en Question ( $\mathrm{n}^{\mathrm{o}} 4$ ). Retrieved from http://www.comenquestion.com/COM\%20 EN\%20QUESTION\%204/COM\%20EN\%20QUESTION\%20PDF/6\%20DRAME.pdf

Eagly, A. H. (2007). Female Leadership Advantage and Disadvantage: Resolving the Contradictions. North western University. Psychology of Women Quarterly, 31(1), 1-12. https://doi.org/10.1111/j.1471-6402.2007.00326.x

Eagly, A. H., Johannessen-Schmidt, M. C., \& van Engen, M. L. (2003). Transformational, transactional, and laissez-faire leadership styles: A meta-analysis comparing women and men. Psychological Bulletin, 129(4), 569-591. https://doi.org/10.1037/0033-2909.129.4.569

Fortier, I. (2008). Les femmes et le leadership. Gestion, 33(3), 61-67. https://doi.org/10.3917/ riges.333.0061

Gauthier, R.-F. (2007). Qui a l'initiative pédagogique? Les Cahiers Pédagogiques, 458, 22-24.

Gilligan, C. (1982). In a Different Voice: Psychological theory and Women's Development. Cambridge: Harvard University Press.

Gross, N., \& Trask, A. (1976). Men and women as elementary principals. Cambridge, Mass.: Harvard University. 


\section{Macrothink}

Harris, A. (2003). The changing context of leadership: Research, theory and practice. In A. Harris, C. Day, D. Hopkins, M. Hadfield, A. Hargreaves, \& C. Chapman (Eds.), Effective Leadership for School Improvement (pp. 9-25). Routledge, New York, NY.

Héon, L., Savard, D., \& Hamel, T. (2008). L. Héon, D. Savard, \& T. Hamel (Eds.), Les cégeps: Une grande aventure collective québécoise (p. 533). Les Presses de l'Université Laval.

Hooks, B. (1994). Teaching to transgress: Education as the practice of freedom (Chapter 1). New York: Routledge.

Joekes, S. P. (1987). Women in the world of economy: An instraw study, UN international research and training for the advancement of women. New York: Oxford University Press.

Jolls, C. (2002). Is there a glass ceiling? Harvard Journal of Law \& Gender, 25(1), 1-18.

Judge, T. A., \& Piccolo, R. F. (2004). Transformational and transactional leadership: A meta-analytic test of their relative validity. Journal of Applied Psychology, 89, 755-768. https://doi.org/10.1037/0021-9010.89.5.755

Kythreotis, A., Pashiardis, P., \& Kyriakides, L. (2010). The influence of school leadership styles and culture on students' achievement in Cyprus primary schools. Journal of Educational Administration, 48(2), 218-240. https://doi.org/10.1108/09578231011027860

Lapointe, P., Brassard, A., Garon, R., Girard, A., \& Ramdé, P. (2011). La gestion des activités éducatives de la direction et le fonctionnement de l'école primaire. Revue Canadienne de l'Éducation, 34(1), 179-214.

Lee, D. R., \& Sweeney, J. P. (2001). An assessment of influence tactics used by project managers. Engineering Management Journal, 13(2), 16-25. https://doi.org/10.1080/10429247. 2001.11415112

Library of Congress Online. (2004). World Atlas. Country Profile: Cote d'Ivoire. Retrieved November 7, 2017, from https://www.worldatlas.com/webimage/countrys/africa/ci.htm

Lortie-Lussier, M., \& Rinfret, N. (2007). La contribution des femmes à l'émergence de nouvelles cultures organisationnelles: Entre réalité et utopie. Télescope, 13(4), 1-13.

Martin, J. (2015). Transformational and Transactional Leadership: An Exploration of Gender, Experience, and institution type. Libraries and the Academy, 15(2), 331-351. https://doi.org/ $10.1353 /$ pla.2015.0015

Mascia, S. (2015). Are women better suited to project leadership than men? Retrieved May 1, 2016, from http://www.gpmfirst.com/articles/opinion/guest-editorial-are-women-better-suited -project-leadership-men

Miles, M. B., \& Huberman, A. M. (2003). Analyse des données qualitatives (2nd ed.). Bruxelles: Édition De Boeck.

MoE. (2016). Données Statistiques de la Direction des Stratégies de la Planification et des 
Statistiques (DSPS). Ministère de l'Éducation National. Retrieved from http://www.men-dpes. org/new/index.php

MoE. (2017). Données Statistiques de la Direction des Stratégies de la Planification et des Statistiques (DSPS). Ministère de 1'Éducation National. Available at http://www.men-dpes. org/new/index.php

Mollel, N., \& Tshabanbu, I. (2014). Women in Educational Leadership: Conceptualizing Gender Perceptions in Tanzanian Schools. Educational Research International, 3(4), 46-54.

Momsen, J. K., \& Kinnaird, V. (1993). Different places: Different voices gender and development in Africa, Asia and Latin America. London: Routledge. https://doi.org/10.4324/ 9780203310953

Moreau, C. (2014). Rapport de la Côte d'Ivoire sur la mise en œuvre du programme d'action de Beijing vingt ans après. Ministère de la Solidarité, de la Famille, de la Femme et de l'Enfant. République de Côte d'Ivoire. Retrieved from https://www.uneca.org/sites/ default/files/uploaded-documents/Beijing20/NationalReviews/cote_divoire_beijing_review_r eport_0.pdf

Morsink, H. (1970). Leader behavior of men and women secondary school principals. NASSP Bulletin, 54(7), 80-87.

Muzvidziwa, I. (2014). Principalship as an empowering leadership process: The experiences of women school heads in Zimbabwe. Anthropologist, 17(1), 213-221. https://doi.org/ $10.1080 / 09720073.2014 .11891431$

Nowack, M. K. (2015). Do Men and Women Lead Differently? Retrieved March 26, 2016, from http://www.clomedia.com/articles/6330-do-men-and-women-lead-differently

Ogawa, R. T., \& Bossert, S. T. (1995). Leadership as an organizational quality. Educational Administration Quarterly, 31(2), 224-43. https://doi.org/10.1177/0013161X95031002004

Ostergaard, L. (Ed.). (1992). Gender and development: A practical guide. London: Routledge.

Oyeniran, R. (2018). Women Educational Leaders in Principalship: Exploring the Lived Experiences of Women Heading Primary Schools in Côte d'Ivoire. International Journal of Contemporary Education, 1(1), 36-51. https://doi.org/10.11114/ijce.v1i1.3209

Patton, M. Q. (2002). Qualitative research and evaluation methods. London: Sage Publisher.

Pont, B., Nusche, D., \& Moorman, H. (2008). Améliorer la direction des établissements scolaires. Improving School Leadership, Volume 1: Politiques et Pratiques. Paris: OCDE. Retreived from http://www.oecd.org/fr/education/scolaire/44374906.pdf

Reinhold, B. (2005). Smashing glass ceilings: Why women still find it tough to advance to the executive suite. Journal of Organisational Excellence, 1, 43-55. https://doi.org/10.1002/ joe. 20054 


\section{Macrothink}

Rigg, C., \& Sparrow, J. (1994). Gender, diversity and working styles. Women in Management Review, 9(1), 9-1. https://doi.org/10.1108/09649429410050971

Rouamba, L., \& Descarries, F. (2010). Les femmes dans le pouvoir exécutif au Burkina Faso (1957-2009). Feminist Research, 23(1), 99-122. https://doi.org/10.7202/044424ar

Sachs, J., \& Blackmore, J. (1998). You never show you can't cope: Women in school leadership roles managing their emotions. Gender and Education, 103(3), 265-279. https://doi.org/10.1080/09540259820899

Shakeshaft, C. (1986). A female organizational culture. Educational Horizons, 64(3), 117-120.

Spillane, J. P., Halverson, R. R., \& Diamond J. B. (2008). Théorisation du leadership en éducation: Une analyse en termes de cognition située. Education et Société, 21, 121-149. https://doi.org/10.3917/es.021.0121

UNESCO. (2013). Adult and youth literacy. National, regional and global trends, 1985-2015. Retrieved from http://unesdoc.unesco.org/images/0021/002174/217409e.pdf

UNESCO. (2016). Education for people and planet: Creating sustainable future for all. Global education monitoring report (2nd ed.). Retrieved from http://unesdoc.unesco.org/ images/0024/002457/245752e.pdf

World Bank. (2017). World Bank annual Report 2017. Retrieved December 27, 2017, from http://pubdocs.worldbank.org/en/908481507403754670/Annual-Report- 2017-WBG.pdf

Wrushen, B. R., \& Sherman, W. H. (2008). Women secondary school principals: Multicultural voices from the field. International Journal of Qualitative Studies in Education (QSE), 21(5), 457-469. https://doi.org/10.1080/09518390802297771

Yin, R. K. (2014). Case Study Research. Design and Methods (5th ed.). Sage Publications, Inc.

\section{Copyright Disclaimer}

Copyright for this article is retained by the author(s), with first publication rights granted to the journal.

This is an open-access article distributed under the terms and conditions of the Creative Commons Attribution license (http://creativecommons.org/licenses/by/3.0/). 